\title{
Charcot and His Passion for Dogs: A Historical Note
}

\author{
Fábio A. Nascimento ${ }^{\text {a }}$ Carlos Henrique Ferreira Camargo ${ }^{b}$ Olivier Walusinski ${ }^{c}$ \\ Hélio Afonso Ghizoni Teive ${ }^{b}$ \\ aDepartment of Neurology, Baylor College of Medicine, Houston, TX, USA; ${ }^{b}$ Department of Medicine, Neurology \\ Division, Universidade Federal do Paraná, Curitiba, Brazil; 'Independent Researcher, Brou, France
}

\section{Keywords}

Jean-Martin Charcot · Charcot · Father of neurology · Pets · Dogs

\begin{abstract}
Jean-Martin Charcot, one of the most brilliant neurologists in history, was a man of few words and few gestures. He had an impenetrable and unmovable face and was described as being austere, reserved, and shy. In contrast, in his personal life, he was a softhearted man who loved animals - especially dogs. In this historical note, we sought to look into the past and learn more about Dr. Charcot's personal life - which was robustly impacted by his passion for dogs.
\end{abstract}

(C) 2020 S. Karger AG, Basel

\section{Manuscript}

Jean-Martin Charcot, born in Paris, France in 1825, is one of the most influential neurologists in history and considered the father of modern neurology. Dr. Charcot was described by many biographers as being austere, reserved, and shy. He was a man of few words and few ges- tures and had an impenetrable and unmovable face. His personality was defined as authoritarian and skeptical, and he was frequently described as having an ironic and sarcastic sense of humor. Nonetheless, in his personal life, he was a softhearted man who was very fond of animals - especially dogs. His love for animals has even been considered zoophilic [1-5].

In one of the most widely known biographies of Dr. Charcot [6], his personality was characterized as: “...Charcot, who was almost silence personified, who would seldom proffer his hand to another, who disdained the banal expressions of politeness, and who seemed to dread human contact, had in absolute contrast a passionate affection for animals. He would talk to them, caress them, make them play; they seemed to make him more extroverted and relaxed."

Dr. Charcot's passion for animals was witnessed both in the medical and personal fronts. In the former, he was explicitly against vivisections and experiments involving animals - including neurophysiological experiments. In fact, these were not allowed to take place at his institution - La Salpêtrière Hospital. Consequently, most of his neuroanatomical and neuropathological studies were based on human autopsies. It has also been noted that he kept a karger@karger.com www.karger.com/ene

(C) 2020 S. Karger AG, Base

Karger!"
Hélio Afonso Ghizoni Teive

Department of Medicine, Neurology Division, Federal University of Paraná $1103 / 102$, General Carneiro St. Curitiba 80060-150 (Brazil)

teiveads@mps.com.br 


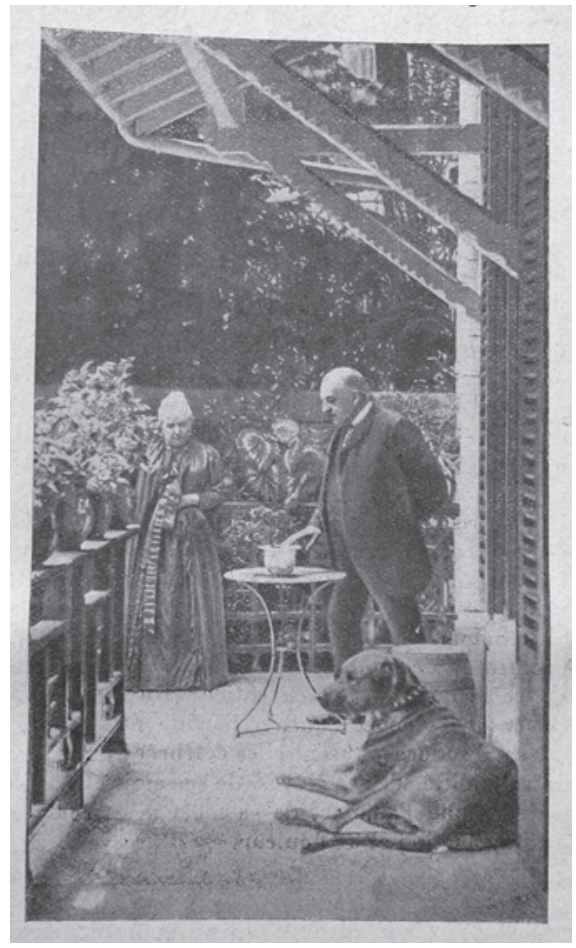

Fig. 1. Mr. and Mrs. Charcot on the terrace of his house in Neuilly alongside his favorite dog, Carlo. Image extracted from Souques A. Charcot in time. Presse Med. 1925;42:693-8.

sign on his office door that read "You will find no dog laboratory here." $[6,7]$.

From a personal standpoint, Dr. Charcot's love for animals was even more evident. He publicly expressed aversion to hunting and bullfighting - the latter defined, in his words, as the hunt in which man does not even have the merit of running danger $[6,7]$. On one occasion, Dr. Charcot was seen chasing a duck in the rescue of a frog caught in its beak [6]. Another biographical article [7] illustrated Dr. Charcot's affection toward animals as follows: "One evening I sat at the table protesting against this "vestige of barbarian times", and chattering his friend, Joffroy and Gombault, fervent hunters, who said a timid reply. One of the most curious characteristics of this sensitivity was his love for animals. He had for the animals a tenderness that the sweet saint Francis of Assisi would have envied". Note that Joffroy and Gombault referred to Alix Joffroy and Albert Gombault, respectively - Dr. Charcot's pupils.

Dr. Charcot loved dogs. He had two at home, which were made company by a small female monkey named Rosalie - given as a gift by Dom Pedro II, Emperor of Bra- zil at the time [8]. Dr. Charcot's home, located at 217 Boulevard Saint-German in Paris, France, always had at least one dog in its premises [6].

In regard to Dr. Charcot's dogs, it was written that “... there was one with whom I had the most friendly and courteous relations, and another huge dog, with the name of Sigurd." The former dog was a Labrador named Carlo (Fig. 1) [6]. Dr. Charcot adored Carlo and, at times, he would sign his letters referring to Carlo: “...several of his letters end with these words: "Embrace Carlo - was the dog"' [7].

Most of us, in addition to the father of the science we all love, love pets. Our true companions have been keeping us company and inspiring us for many centuries. From a medical standpoint, the interaction between animals and humans has been repeatedly associated with better health - including reduction in depression, loneliness, and anxiety as well as improvement in social interaction and physical activity levels. In fact, a recent major meta-analysis involving more than 3 million subjects showed that dog ownership is associated with decreased overall mortality, possibly due to reduction in cardiovascular deaths [9]. It should be noted that Dr. Charcot ironically passed away due to acute pulmonary edema as a result of a myocardial infarction [10]. Moreover, there are suggestions that pet ownership modulates autonomic nervous activity imbalance in patients with lifestyle-related diseases (such as diabetes, hypertension, and hyperlipidemia) [11]. However, it is important to emphasize that there are also challenges related to pet ownership such as allergies, zoonoses, animal bites, and falls. Additionally, one should not overlook the financial burden brought by caring for pets [12].

Returning to Dr. Charcot, not only did we learn about his passion for dogs but also how he had different personas - one at work and one at home. In reality, many of us have home and work personas, irrespective of the time, place, or profession. Even during recent times, when the pace of life coupled with technology may mandate that we bring our work home, most of us still adopt different personalities depending on the circumstances. At times, home and work personas are notably different, for example, with Dr. Charcot. While the father of neurology was austere and severe at work, he was kind and tender at home - reflected by his absolute passion for animals, love for his family, and warm hospitality during home gatherings with colleagues. We should learn how to traverse between our various personas, as Dr. Charcot did, in order to achieve similar success in our personal and professional lives. 


\section{Statement of Ethics}

This study was conducted ethically and in compliance with the appropriate guidelines.

\section{Conflict of Interest Statement}

F.A.N., C.H.F.C., O.W., and H.A.G.T. report no disclosures relevant to the manuscript.

\section{Funding Sources}

This study was not funded.

\section{Statement of Authorship}

F.A.N.: data analysis and interpretation, and drafting manuscript. C.H.F.C.: data analysis and interpretation. O.W.: data analysis and interpretation, and revising manuscript. H.A.G.T.: study concept and design, data analysis and interpretation, study supervision, revising manuscript, and final approval. All authors accept responsibility for conduct of the research.

\section{References}

1 Bonduelle M. [The intimate Charcot]. Rev Neurol. 1994;150(8-9):524-8.

2 Goetz CG, Bonduelle M, Gelfand T. Charcot: constructing neurology. New York: Oxford University Press; 1995.

3 Silva MME, Meira AT, Walusinski O, Camargo CHF, Teive HAG. Charcot's paradox. Arq Neuropsiquiatr. 2019;77(8):590-3.

4 Lellouch A. Jean-Martin Charcot et les origins de la geriatrie. Paris: Payot; 1993.

5 Poirier J. Jean-Martin Charcot (1825-1893): sa personne, sa personality, son personnage. Neurologie Liberale. 2013 Jul-Sep.
6 Guinon G. Charcot intime. Paris Medical. 1925;56:511-6.

7 Souques A. Charcot intime. La Presse Medicale. 1925;42:693-8.

8 Teive HA, Arruda WO, Werneck LC. Rosalie: the Brazilian female monkey of Charcot. Arq Neuropsiquiatr. 2005;63(3A):707-8.

9 Kramer CK, Mehmood S, Suen RS. Dog ownership and survival: a systematic review and meta-analysis. Circ Cardiovasc Qual Outcomes. 2019;12(10):e005554.
10 Teive HAG, Marques P, Germiniani FMB, Walusinski O. Requiem for a neurologist: the funeral rites of Jean-Martin Charcot. Arq Neuropsiquiatr. 2017;75(11):827-9.

11 Aiba N, Hotta K, Yokoyama M, Wang G, Tabata M, Kamiya K, et al . Usefulness of pet ownership as a modulator of cardiac autonomic imbalance in patients with diabetes mellitus, hypertension, and/or hyperlipidemia. Am J Cardiol. 2012;109(8):1164-70.

12 Friedman E, Krause-Parello CA. Companion animals and human health: benefits, challenges, and the road ahead for human-animal interaction. Rev Sci Tech. 2018;37(1):71-82. 